\title{
Effects of Salinity on Seedling Growth of Four Maize (Zea Mays L.) Cultivars Under Hydroponics
}

\author{
Snehasish Bose \\ Department of Seed Science and Technology, \\ Bangladesh Agricultural University, Mymensingh, Bangladesh. \\ Oli Ahmed Fakir \\ Bangladesh Agricultural Research Institute, \\ Benarpota, Satkhira, Bangladesh. \\ Mahbubul Islam \\ Bangladesh Agricultural Research Institute, Gazipur, Bangladesh. \\ Md Khairul Alam (Corresponding author) \\ Murdoch University, Perth, Western Australia, Australia. \\ E-mail: khairul.krishi@gmail.com
}

A. K. M. Zakir Hossain \& Alamgir Hossain

Department of Crop Botany, Bangladesh Agricultural University,

Mymensingh, Bangladesh.

\section{H. Rashid}

Global Centre for Environmental Remediation (GCER),

University of Newcastle, Callaghan-2308, NSW Australia.

Received: October 28, 2017

doi:10.5296/jas.v6i1.12401
Accepted: November 13, 2017

URL: https://doi.org/10.5296/jas.v6i1.12401 


\section{Abstract}

Growth and development of a crop or even cultivars within a species of a crop respond to soil salinity since germination. A hydroponic experiment was conducted at Plant Physiology Laboratory, Department of Crop Botany, Bangladesh Agricultural University, Mymensingh, Bangladesh, during the period from December 2015 to July 2016 to investigate the effect of $\mathrm{NaCl}$ on morphological characters and growth of maize (Zea mays L.) seedlings. The experiment comprised two levels $\left(0 \mathrm{dS} \mathrm{m}^{-1}\right.$ and $\left.8 \mathrm{dS} \mathrm{m}^{-1}\right)$ of salinity for hydroponic experiment, designed in two factorials Complete Randomized Design (CRD) with three replications on four cultivars viz. Kaveri - 244+, BHARAT Hybrid Sultan 702, Getco seeds GP-901, Essence-Platinum. Results indicated that root and shoot length, number of leaves plant $^{-1}$, fresh and dry mass production varied with $\mathrm{NaCl}$ stress which indicating that some cultivars of maize seedlings are highly susceptible to concentrated $\mathrm{NaCl}$. However, among tested cultivars, Essence-Platinum showed the best performance considering the seedlings growth and other parameters. BHARAT Hybrid Sultan 702, Getco seeds GP - 901 showed the highest sensitivity to $\mathrm{NaCl}$ stress in this experiment based on the above parameters studied.

Keywords: Hydroponic, $\mathrm{NaCl}$ stress, root length, sensitivity and shoot length

\section{Introduction}

Of the 1128 million hectare (Mha) of salt-affected area in the world (Wicke et al., 2011), 226 Mha of land are irrigated (Pitman \& Läuchli, 2002). Farmers grow maize (Zea mays L.) as an important food grain in all climates from tropical to warm prevailed in various parts of the world. In 2016, world maize production was approx. 1067 million tons (USDA, 2016). The crop meets up human diet with the nutritional quality of the grain, while stressful abiotic conditions such as cold temperature, water and salinity stresses reduces its performance in terms of production (Fita et al., 2015). Therefore, study on the tolerance of maize cultivars to salinity through evaluation and selection of maize cultivars is a great necessity so that an efficient technique can be developed for the purpose (Hoque et al., 2015). The effect of salinity on a crop is variable at different growth stages (Banziger et al., 2007). A very high genotypic variability in maize cultivars exists for resistance to salinity and drought at the seedling stage. Diverse genotypes of the crop have also been selected for resistance to drought and salinity stresses (Maiti et al., 2012).

In recent studies, considerable variations were observed in the root, shoot length and biomass of different hybrids at different salinity levels (Cramer et al., 1990; Maiti et al., 1996, Maiti et $a l ., 2012)$. The effect of increased salinity concentrations at germinating stage and seedling stage of maize are more adverse than the effects at later stages of the growth (Lianes et al., 2005, Maiti et al., 2012). Salinity causes several biochemical changes in various crops which have been documented in the literature. Maize crop at the germination stage transported high amount of $\mathrm{Na}^{+}$and $\mathrm{Cl}^{-}$to the growing part of shoot and in course of time, $\mathrm{K}^{+}$and $\mathrm{Ca}^{2+}$ concentrations decreased in the tissues located in embryonic part (Ashraf and Wahid, 2000.). Seed lipids during germination break down in order for supplying sugars in soluble forms in the metabolism of the growing embryo (Kochak-Zadeh et al., 2013). Several studies have been undertaken to understand the mechanism of tolerance to salinity in maize and other 
crops (Tester and Davenport, 2003, Datta et al., 2009, Khan et al., 2003, Nordquist et al., 1992). The effects of salinity on plant growth are associated with osmotic ion and oxidative stress. Halophytes and glycophytes got adjusted osmotically with the increase in accumulated solutes in organic and inorganic forms (Shrivastava and Kumar, 2015) which eventually causes greater decrease in cell solute potential than external salt concentration. This may be attributed to balancing of the accumulated organic solutes in the cytosol with the solute potential of the ions-dominated-vacuoles (Slam et al., 2015). A positive correlation between osmolyte accumulation and the adaptation to stress has been well documented. Molecular mechanism of salt tolerance has been well acknowledged by different authors (Gupta and Huang, 2014).

When plants go through salinity stress, characteristic changes begin from germination until maturity (Munns, 2002) which can be becoming unproductive or wilting and doughtiness, even if soils are wet and moist. The increasing amount of lands degraded by salinity and population increase at the same time drive researchers to develop crops capable of growing under saline conditions so that salinity affected soils can be brought under cultivation (Munns et al., 2006; Yamaguchi \& Blumwald, 2005). Maize, a crop which coverage is increasing every year for its various purpose of use, is very salt-sensitive, shows obvious signs of stress, including wilting even when there is adequate soil moisture (Farooq et al., 2015). Ouda et al. (2008) recorded retarded maize growth characters and yield potential grown under salinity stress. Again, they also observed contrasting results of moderately sensitiveness of the crop with $\mathrm{C} 4$ metabolic characters to salinity to soil salinity. Genetic variations for salt tolerance in maize crop were also recorded by Maiti et al. (1996). Different researchers found early seedling stage of maize and of all crops the sensitive period mostly affected by salinity stress while growth of crops decreased with increase in salinity (Shalhevet, 1995). Seedling weight and growth rate and root parameters under stress condition are selected traits in studying maize in terms of salt tolerance and/or resistance. So, the present study aims at evaluating the following objectives.

a To find out the effect of salinity on growth and development of maize seedlings in hydroponic culture.

b To examine the salinity tolerance inconsistency among the maize cultivars.

\section{Materials and Methods}

\section{Planting Materials}

The seeds of four maize varieties namely cv. Kaveri-244+, cv. BHARAT Hybrid Sultan 702, cv. Getco seeds GP-901, cv. Essence-Platinum were collected from Bangladesh Agriculture Research Institute (BARI) and used as experimental materials.

\section{Experimental Laboratory}

The Experiment was conducted at Crop Physiology Laboratory, Department of Crop Botany, Bangladesh Agricultural University, Mymensingh, Bangladesh during the period from December, 2015 to July, 2016. 


\section{Macrothink}

\section{Pot Preparation}

The black colored pots were taken with Hogland's full strength nutrient solutions and an aeration pump was attached to supply oxygen into the water. After this, the experimental pots were laid out as per treatments and design.

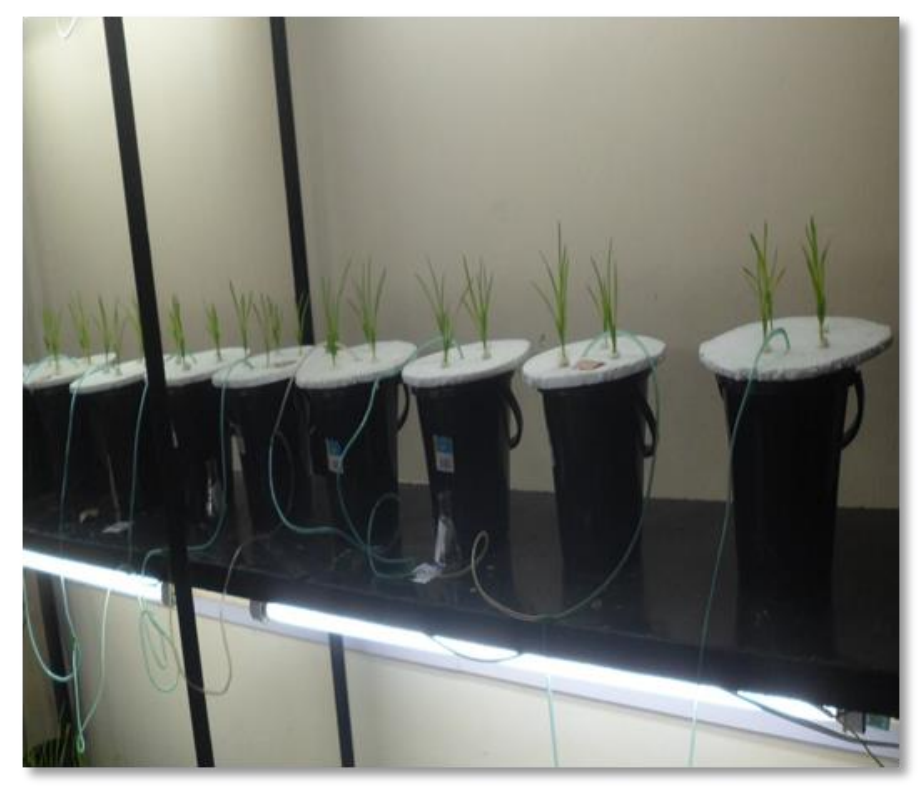

Figure 1. Preparation of black color pots with maize seedlings

\section{Experimental Design}

The experiment was laid out in Completely Randomized Design (CRD) with three replications having two treatments comprising $\mathrm{NaCl}$ application. The individual pot size was $8 \mathrm{~L}$. Each treatment received equal amount of macro and micro nutrients. Total number of water tank used in this study were $(4 \times 3 \times 2)=24$. The treatments were randomly distributed to the tank. All the experiments were conducted in a growth room at $25^{\circ} \mathrm{C}$ under a 12 hour-light and 12 hour-dark regime, $70 \%$ relative humidity and $\mathrm{pH}$ adjusted at 6.5 .

\section{Application of $\mathrm{NaCl}$ and Nutrients}

During germination stage, $\mathrm{NaCl}$ solution of $8 \mathrm{dSm}^{-1}$ concentration was sprayed to the seeds on Petri dishes for $\mathrm{T}_{2}$ and distilled water was sprayed to the seeds on Petri dishes of control treatments to ensure $0 \mathrm{dS} \mathrm{m}{ }^{-1}$. All other nutrients except $\mathrm{NaCl}$ were incorporated to the tank at recommended dose (Table 1). Eight (8) $\mathrm{dS} \mathrm{m}^{-1} \mathrm{NaCl}$ solutions were added to the water into the tank at an eight days interval.

\section{Hydroponic Experimental Set Up}

One-week-old seedlings were transferred to continuously aerated nutrient solution in $8 \mathrm{~L}$ plastic tank on Styrofoam blocks with 4 holes and three plants per hole, supported with sponge. The solution was renewed with fresh nutrient solutions in 8 days interval. The composition of the nutrient solution was presented below: 


\section{Macrothink}

Table 1. Nutrient sources and the recommended dose used for the experiment

\begin{tabular}{|l|c|}
\hline \multicolumn{1}{|c|}{ Source } & Dose \\
\hline $\mathrm{NH}_{4} \mathrm{NO}_{3}$ & $500 \mu \mathrm{M}$ \\
\hline $\mathrm{Ca}\left(\mathrm{NO}_{3}\right)_{2}$ & $500 \mu \mathrm{M}$ \\
\hline $\mathrm{MgSO}_{4}$ & $200 \mu \mathrm{M}$ \\
\hline $\mathrm{KH}_{2} \mathrm{PO}_{4}$ & $100 \mu \mathrm{M}$ \\
\hline $\mathrm{FeCl}_{3}$ & $2 \mu \mathrm{M}$ \\
\hline $\mathrm{H}_{2} \mathrm{BO}_{3}$ & $11 \mu \mathrm{M}$ \\
\hline $\mathrm{MnCl}_{2}$ & $2 \mu \mathrm{M}$ \\
\hline $\mathrm{ZnCl}_{2}$ & $0.35 \mu \mathrm{M}$ \\
\hline $\mathrm{CuCl}_{2}$ & $0.2 \mu \mathrm{M}$ \\
\hline$\left(\mathrm{NH}_{4}\right)_{6} \mathrm{Mo}_{7} 0_{4}$ & $0.1 \mu \mathrm{M}$ \\
\hline
\end{tabular}

\section{Data Collection}

Data on the following parameters at the transfer day of seedling to plastic tank on Styrofoam blocks (0 Das) and 14 days after transfer (14 DAS) were recorded. The following morphological characteristics at selected stages of seedlings were collected: (a) Root length (b) Shoot length (c) No. of leaves/plant (d) Fresh weight of root and shoot (e) Dry weight of root and shoot. After collection of data of maize seedlings, 0 and 14 DAS maize seedling's root and shoot of selected varieties was collected and dried. The seedlings were collected and prepared to study the fresh and dry weight. The weights of 4 fresh seedlings were recorded and the seedlings were placed in an oven for $24 \mathrm{hrs}$ at $80 \pm 2^{\circ} \mathrm{C}$. Then the dry weights were measured using an electrical balance.

\section{Statistical Analysis}

Data were statistically analyzed for analyses of variance (ANOVA) using the M-STAT Statistical Computer Package Programme in accordance with the principles of Completely Randomized Design (CRD). Duncan's Multiple Range Test (DMRT) was used to compare variations among the treatments. 


\section{Macrothink}

\section{Results and Discussion}

\section{Effect of $\mathrm{NaCl}$ levels on crop characters of maize grown in hydroponic culture}

\section{Root length}

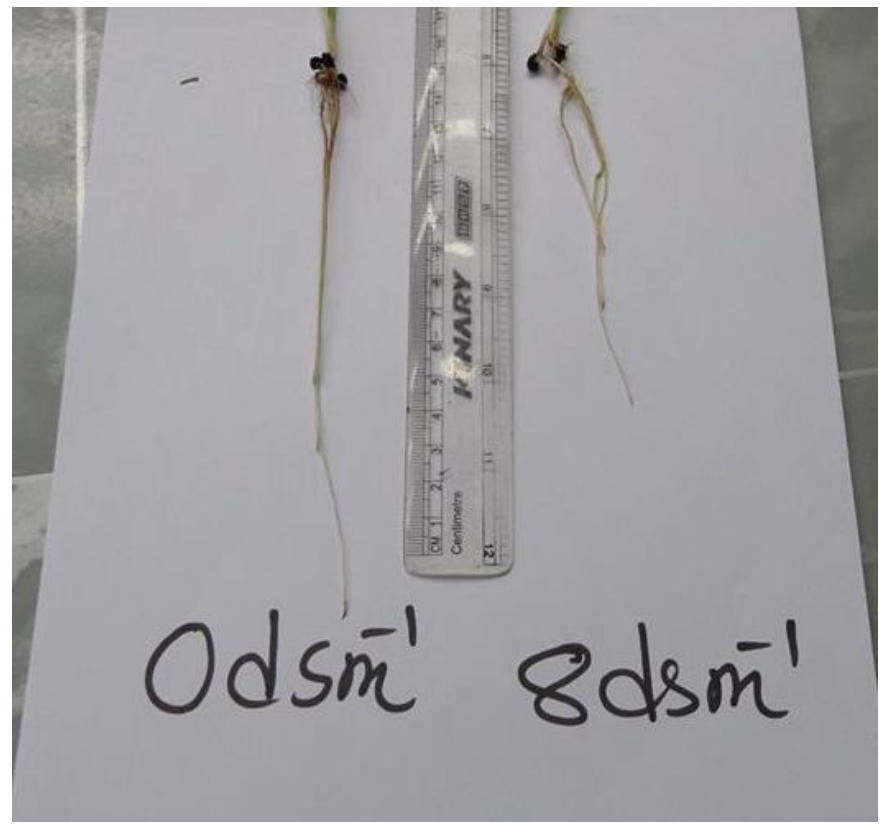

Figure 2. Effect of $\mathrm{NaCl}$ on root length of maize (Zea mays $\mathrm{L}$.

The effect of variety and $\mathrm{NaCl}$ on root length was interactively significant ( $\mathrm{p}<0.01$ ) (Figure 2 and 3). The highest root length was observed in the treatment combination of Essence-Platinum with $0 \mathrm{dS} \mathrm{m} ~^{-1} \mathrm{NaCl}(512 \mathrm{~mm})$ which was statistically similar to Getco seeds GP - 901 (under stress condition) and the lowest was recorded in the treatment combination of BHARAT Hybrid Sultan 702 with $8 \mathrm{dS} \mathrm{m}^{-1} \mathrm{NaCl}(201 \mathrm{~mm})$.

The significant differences observed among cultivars and salinity ( $\mathrm{NaCl}$ levels) with respect root length is similar to study of Hoque et al. (2015) and Ashraf et al. (2005). No salt (0 dS $\mathrm{m}^{-1}$ ) in culture medium significantly enhanced root length. As root growth is highly sensitive to high salt concentrations in the medium. That is why roots are rapidly reduced or prevented by salinity (Ashraf et al., 2005). The decrease in root growth can also be attributed to root damage by salinity stress or stunted growth of leaves under salinity level increase. In spite of decreasing the root length of all cultivars at 14 DAS under increased salinity level, Getco seeds GP - 901 and Essence -Platinum cultivars had significantly higher root length than Kaveri - 244+ and BHARAT Hybrid Sultan 702 cultivars. 


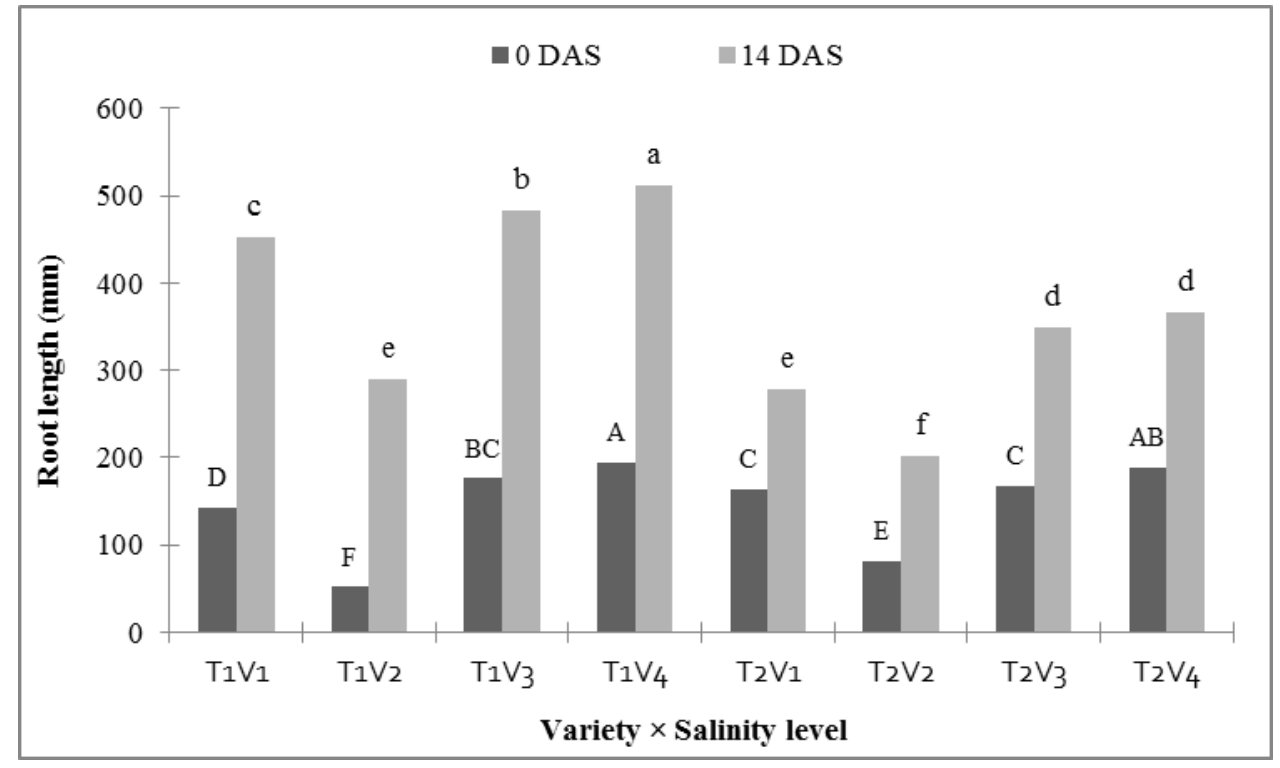

Figure 3. Combined effect of salinity level and varieties on root length of maize cultivars

Here, $\mathrm{T}_{1}$ and $\mathrm{T}_{2}$ mean $0 \mathrm{dS} \mathrm{m}^{-1}$ and $8 \mathrm{dS} \mathrm{m}^{-1}$, respectively; maize cultivars were $\mathrm{V}_{1}$ : Kaveri $244+, \mathrm{V}_{2}$ : BHARAT Hybrid Sultan 702, $\mathrm{V}_{3}$ : Getco seeds GP - 901, and $\mathrm{V}_{4}$ : Essence

-Platinum. Least Significant Difference $\left(\mathrm{LSD}_{0.05}\right)$ for 0 DAS and 14 DAS are 14.2 and 28.7, respectively. Columns with the same letter are not significantly different from each other.

\section{Shoot Length}

Effect of variety in combination with salinity on shoot length at 0 and 14 DAS was significant $(\mathrm{p}<0.05)$ (Table 2). At 14 DAS, the highest shoot length was recorded in the treatment combination of Essence-Platinum and $0 \mathrm{dS} \mathrm{m}^{-1} \mathrm{NaCl}(476 \mathrm{~mm})$. The lowest shoot length was recorded in BHARAT Hybrid Sultan 702 with $8 \mathrm{dS} \mathrm{m} \mathrm{m}^{-1} \mathrm{NaCl}$ (197 mm). Under stress condition, Getco seeds GP - 901 and Platinum-Essence had statistically similar shoot length. A 44\% decrease in shoot length was observed in BHARAT Hybrid Sultan 702 followed by $20 \%$ in Essence -Platinum with the increase in salinity level. All the maize cultivars had decreased shoot growth with increased $\mathrm{NaCl}$ concentration (Pessarakli and Kopec, 2009). Similar results were observed by Hoque et al. (2015) in maize, Mohammad et al. (1998) in tomato and by Gill and Singh (1989) in rice. The reduction in shoot length is due to excessive accumulation of salts in the cell wall elasticity (Hoque et al., 2015). Additionally, there soon appears secondary cell with rigid cell walls which might results in decreased cell enlargement. 
Table 2. Combined effect of salinity level and varieties on shoot length of maize

\begin{tabular}{|c|c|c|c|}
\hline \multirow{2}{*}{ Treatment } & \multirow{2}{*}{ Variety } & \multicolumn{2}{|c|}{ Shoot length (mm) } \\
\hline & & 0 DAS & 14 DAS \\
\hline \multirow{4}{*}{$\mathrm{T}_{1}$} & $\mathrm{~V}_{1}$ & $214 \mathrm{c}$ & $466 a$ \\
\hline & $\mathrm{V}_{2}$ & $70 \mathrm{~d}$ & $352 \mathrm{c}$ \\
\hline & $\mathrm{V}_{3}$ & $224 \mathrm{bc}$ & $462 \mathrm{a}$ \\
\hline & $\mathrm{V}_{4}$ & $259 \mathrm{a}$ & 476 a \\
\hline \multirow{4}{*}{$\mathrm{T}_{2}$} & $\mathrm{~V}_{1}$ & $229 \mathrm{~b}$ & $377 \mathrm{~b}$ \\
\hline & $\mathrm{V}_{2}$ & $59 \mathrm{e}$ & $197 \mathrm{~d}$ \\
\hline & $\mathrm{V}_{3}$ & $224 \mathrm{~b}$ & $378 \mathrm{~b}$ \\
\hline & $\mathrm{V}_{4}$ & $252 \mathrm{a}$ & $377 \mathrm{~b}$ \\
\hline \multicolumn{2}{|c|}{$\mathrm{LSD}_{0.05}$} & 9.7 & 22.0 \\
\hline \multicolumn{2}{|c|}{ Level of significance } & $* *$ & $* *$ \\
\hline \multicolumn{2}{|c|}{$\mathrm{CV}(\%)$} & 2.9 & 3.3 \\
\hline
\end{tabular}

Here, $\mathrm{T}_{1}$ and $\mathrm{T}_{2}$ means $0 \mathrm{dSm}^{-1}$ and $8 \mathrm{dSm}^{-1}$, respectively; maize cultivars were $\mathrm{V}_{1}$ : Kaveri $244+, \mathrm{V}_{2}$ : BHARAT Hybrid Sultan 702, $\mathrm{V}_{3}$ : Getco seeds GP-901, and $\mathrm{V}_{4}$ : Essence -Platinum. ${ }^{*}=$ Significant at $1 \%$ level of probability.

\section{Number of leaves plant ${ }^{-1}$}

The interaction effect of variety and $\mathrm{NaCl}$ level on no. of leaves plant ${ }^{-1}$ was significant (Table 3). The highest no. of leaves plant ${ }^{-1}$ was recorded in the treatment combination of Essence-Platinum with $0 \mathrm{dSm}^{-1} \mathrm{NaCl}$ at $14 \mathrm{DAS}$ (14.4). On the other hand, the lowest no. of leavesplant $^{-1}$ was observed in BHARAT Hybrid Sultan 702 with $8 \mathrm{dS} \mathrm{m}^{-1} \mathrm{NaCl}$ (4.4) at 14 DAS. Leaf number was decreased with increasing in salt concentration in all maize genotypes except Getco seeds GP-901.The number of leaves of the studied cultivars was varied in response to salinity stress. With the increase in salinity level from $0 \mathrm{dsm}^{-1}$ to $8 \mathrm{dsm}^{-1}$, number of leaves was highly affected in Kaveri-244+, though the lowest leaves was recorded with BHARAT Hybrid Sultan 702. BHARAT Hybrid Sultan 702 with no salinity also had lower leaf numbers at 14 DAS. Among other cultivars, Getco seeds GP-901 had increased numbers of leaves with $8 \mathrm{ds} \mathrm{m}^{-1}$ than with no salinity condition. This behavior indicates a reduction in the appearance of new leaves except Getco seeds GP-901 could be associated with the osmotic stress pointed out by Munns et al. (2002) and Munns and Tester (2008). 


\section{Macrothink}

Journal of Agricultural Studies

ISSN 2166-0379

2018, Vol. 6, No. 1

The slight increase in shoot biomass in Kaveri - 244+ and decrease in root biomass does not show consistent performance. Besides, biomass of Kaveri - 244+ is much lower than Getco seeds GP- 901 and Essence-Platinum.

Table 3. Combined effect of salinity level and varieties on no. of leaves plant ${ }^{-1}$

\begin{tabular}{|c|c|c|c|}
\hline \multirow{2}{*}{ Treatment } & \multirow{2}{*}{ Variety } & \multicolumn{2}{|c|}{ No. of leaves plant ${ }^{-1}$} \\
\hline & & 0 DAS & 14 DAS \\
\hline \multirow{4}{*}{$\mathrm{T}_{1}$} & $\mathrm{~V}_{1}$ & 4.9 & $10.7 \mathrm{c}$ \\
\hline & $\mathrm{V}_{2}$ & 1.7 & $5.0 \mathrm{e}$ \\
\hline & $\mathrm{V}_{3}$ & 5.9 & $10.4 \mathrm{c}$ \\
\hline & $\mathrm{V}_{4}$ & 9.0 & $14.4 \mathrm{a}$ \\
\hline \multirow{4}{*}{$\mathrm{T}_{2}$} & $\mathrm{~V}_{1}$ & 4.6 & $7.9 \mathrm{~d}$ \\
\hline & $\mathrm{V}_{2}$ & 1.4 & $4.4 \mathrm{e}$ \\
\hline & $\mathrm{V}_{3}$ & 7.0 & $11.3 \mathrm{c}$ \\
\hline & $\mathrm{V}_{4}$ & 9.0 & $13.0 \mathrm{~b}$ \\
\hline \multicolumn{2}{|c|}{$\mathrm{LSD}_{0.05}$} & 0.8 & 0.9 \\
\hline \multicolumn{2}{|c|}{ Level of significance } & NS & $* *$ \\
\hline \multicolumn{2}{|c|}{$\mathrm{CV}(\%)$} & 8.0 & 5.4 \\
\hline
\end{tabular}

Here, $\mathrm{T}_{1}$ and $\mathrm{T}_{2}$ means $0 \mathrm{dS} \mathrm{m}^{-1}$ and $8 \mathrm{dSm}^{-1}$, respectively; maize cultivars were $\mathrm{V}_{1}$ : Kaveri-244+, $\mathrm{V}_{2}$ : BHARAT Hybrid Sultan 702, $\mathrm{V}_{3}$ : Getco seeds GP-901, and $\mathrm{V}_{4}$ : Essence -Platinum. $* *=$ Significant at $1 \%$ level of probability, NS=Non-significant.

\section{Fresh Weight}

Variety with salinity level varied fresh weight of root and shoot at 0 and $8 \mathrm{dS} \mathrm{m}^{-1}$ ( $\mathrm{p}<0.01$ ) (Figure 3). The highest fresh weight of root and shoot (23.09 and $22.96 \mathrm{~g} \mathrm{plant}^{-1}$, respectively) were recorded in the treatment combination of Essence - Platinum and $0 \mathrm{dS} \mathrm{m}^{-1} \mathrm{NaCl}$. The lowest fresh weight of root and shoot (3.2 and $2.3 \mathrm{~g} \mathrm{plant}^{-1}$, respectively) were observed in BHARAT Hybrid Sultan 702 with $8 \mathrm{dS} \mathrm{m} \mathrm{m}^{-1} \mathrm{NaCl}$. Higher $\mathrm{NaCl}$ content might cause clampdown early seedling growth due to osmotic stresses, accordingly shoot and root fresh weight reduced considerably as salt concentration increased (Giaveno et al., 2007). Root fresh weight decreased with increased salinity stress. As the root length and root mass decreased with the higher salinity level, the fresh root growth also decreased. Hoque et al. (2015), Hameed et al. (2008) also claimed that fresh weight of root got mostly adversely 


\section{Macrothink}

affected by the increased salt level. The increase in salinity levels decreases the overall biomass production (Hussain et al., 2009).

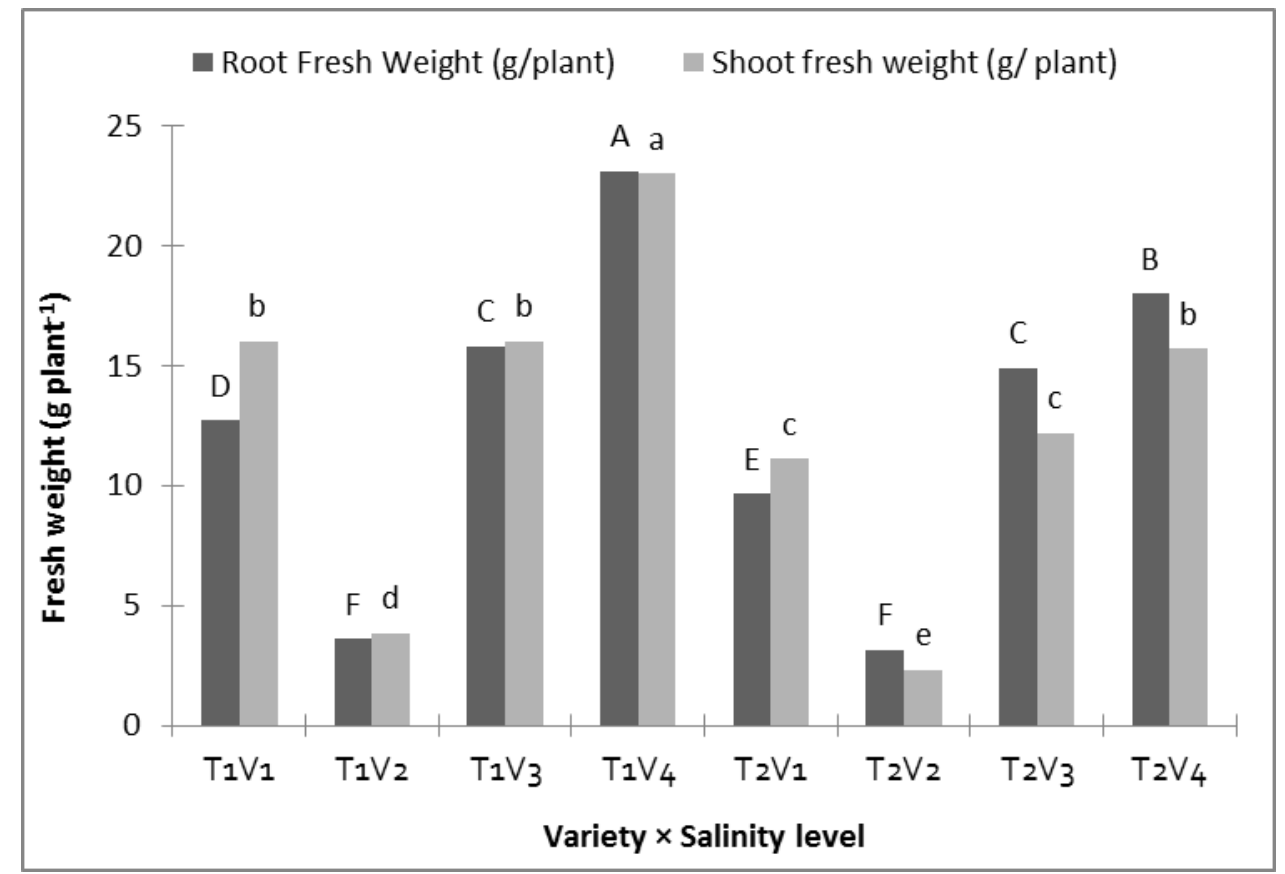

Figure 4. Combined effect of salinity level and varieties on fresh weight of root and shoot

Here, $\mathrm{T}_{1}$ and $\mathrm{T}_{2}$ mean $0 \mathrm{dS} \mathrm{m}^{-1}$ and $8 \mathrm{dS} \mathrm{m}^{-1}$, respectively; maize cultivars were $\mathrm{V}_{1}$ : Kaveri 244+, $\mathrm{V}_{2}$ : BHARAT Hybrid Sultan 702, $\mathrm{V}_{3}$ : Getco seeds GP - 901, and $\mathrm{V}_{4}$ : Essence -Platinum. $\mathrm{LSD}_{0.05}$ for root fresh weight and shoot fresh weight are 1.25 and 1.13 , respectively. Columns with the same letter are not significantly different from each other.

\section{Dry weight}

The interaction effect of variety and $\mathrm{NaCl}$ level on dry weight of root and shoot with $0 \mathrm{dS} \mathrm{m}^{-1}$ and $8 \mathrm{dS} \mathrm{m}^{-1}$ were significant (Table 4). The highest dry weight of root and shoot $(0.98 \mathrm{~g}$ plant $^{-1}$ and $1.33 \mathrm{~g} \mathrm{plant}^{-1}$, respectively) were recorded in the treatment combination of Essence-Platinum with $0 \mathrm{dSm}^{-1} \mathrm{NaCl}$. On the other hand, the lowest dry weight was observed in BHARAT Hybrid Sultan 702 with $8 \mathrm{dS} \mathrm{m}^{-1} \mathrm{NaCl}\left(0.17 \mathrm{~g} \mathrm{plant}^{-1}\right)$ and $\left(0.21 \mathrm{~g} \mathrm{plant}^{-1}\right)$, respectively. Root dry weight of all maize cultivars except Kaveri - 244+ showed a decline towards increase in salinity level (Akram et al., 2007). As a significant reduction in root and shoot biomass was recorded under increased salinity, so the dry biomass also reduced (Hussain et al., 2009). 


\section{Ml Macrothink}

Journal of Agricultural Studies

ISSN 2166-0379

2018, Vol. 6, No. 1

Table 4. Combined effect of salinity level and varieties on dry weight of root and shoot

\begin{tabular}{cccc}
\hline Treatment & Variety & Root dry weight $(\mathrm{g})$ & Shoot dry weight $(\mathrm{g})$ \\
\hline & $\mathrm{V}_{1}$ & $0.45 \mathrm{e}$ & $0.89 \mathrm{~d}$ \\
& $\mathrm{~V}_{2}$ & $0.23 \mathrm{f}$ & $0.23 \mathrm{e}$ \\
$\mathrm{T}_{1}$ & $\mathrm{~V}_{3}$ & $0.80 \mathrm{~b}$ & $0.97 \mathrm{c}$ \\
& $\mathrm{V}_{4}$ & $0.98 \mathrm{a}$ & $1.33 \mathrm{a}$ \\
& $\mathrm{V}_{1}$ & $0.42 \mathrm{e}$ & $0.90 \mathrm{~d}$ \\
& $\mathrm{~V}_{2}$ & $0.17 \mathrm{f}$ & $0.21 \mathrm{e}$ \\
& $\mathrm{V}_{3}$ & $0.60 \mathrm{~d}$ & $0.86 \mathrm{~d}$ \\
$\mathrm{~T}_{2}$ & $\mathrm{~V}_{4}$ & $0.68 \mathrm{c}$ & $1.17 \mathrm{~b}$ \\
& & 0.077 & 0.055 \\
Level of significance & $* *$ & $* *$ \\
CV (\%) & & 8.72 & 2.86 \\
\hline
\end{tabular}

Here, $\mathrm{T}_{1}$ and $\mathrm{T}_{2}$ means $0 \mathrm{dSm}^{-1}$ and $8 \mathrm{dSm}^{-1}$, respectively; maize cultivars were $\mathrm{V}_{1}$ : Kaveri $244+, \mathrm{V}_{2}$ : BHARAT Hybrid Sultan 702, $\mathrm{V}_{3}$ : Getco seeds GP-901, and $\mathrm{V}_{4}$ : Essence -Platinum. $* *=$ Significant at $1 \%$ level of probability.

Considering the reduction of dry mass production under $\mathrm{NaCl}$ results showed that the reduction of dry mass due to $\mathrm{NaCl}$ toxicity was minimum in Essence - Platinum and a slight increase in Kaveri - 244+. On the other hand, the maximum reduction in dry mass production was observed in BHARAT Hybrid Sultan 702 indicating these genotypes were more susceptible to $\mathrm{NaCl}$ toxicity than the other genotypes in maize. The slight increase in shoot biomass in Kaveri - 244+ and decrease in root biomass does not show consistent performance. Besides, biomass of Kaveri - 244+ is much lower than Getco seeds GP - 901 and Essence-Platinum.

\section{Conclusions}

The interaction effect of variety and $\mathrm{NaCl}$ on root and shoot length, no. of leaves plant ${ }^{-1}$ was significant. The highest numbers of leaves plant $^{-1}$, fresh and dry weight of root and shoot were recorded in the treatment combination of Essence -Platinum with control $\left(0 \mathrm{dS} \mathrm{m}^{-1}\right.$ $\mathrm{NaCl}$ ). In genotypes, the highest root and shoot length was observed in Essence -Platinum which resulted the highest dry mass per plant at 0 and 14 DAS. In contrast, the lowest fresh and dry weight was observed in BHARAT Hybrid Sultan 702. From the results, it could be concluded that all the studied Zea mays cultivars were variably affected in growth and development of seedlings by $8 \mathrm{dS} \mathrm{m} \mathrm{m}^{-1}$ level of salinity; among the cultivars Essence 
-Platinum was found comparatively more tolerant under $8 \mathrm{dS} \mathrm{m}^{-1}$ level of saline condition than the other varieties in respect of growth and development.

\section{Acknowledgements}

The author expresses his gratefulness to all of the teachers especially research supervisor and co-supervisor of the Department of Crop Botany, Bangladesh Agricultural University, Mymensingh, for their help, valuable suggestions and kind co-operations throughout the period of research work and preparation of the manuscript.

\section{References}

Akram, M., Asghar, M. M., Yasin, A. M., Farrukh, S. M., \& Hussain, M. (2007). Competitive seedling growth and $\mathrm{K}+/ \mathrm{Na}+$ ratio in different maize (Zea mays $\mathrm{L}$ ). hybrids under salinity stress. Pak. J. Bot., 39(7): 2553-2563.

Ashraf, M., \& Wahid, S. (2000). Time-course changes in organic metabolites and mineral nutrients in germinating maize seeds under salt $(\mathrm{NaCl})$ stress. Seed Science Technology, 28: 641-656.

Ashraf, M. Y., Akhtar, K., Sarwar, G., \& Ashraf, M. (2005). Role of rooting system in salt tolerance potential of different guar accessions. Agron. Sust. Dev., 25: 243-249.

https://doi.org/10.1051/agro:2005019

Banziger, M., Setimela, P., Hodson, D., \& Vivek, B. (2006). Breeding for improved abiotic stress tolerance in maize adapted to southern Africa. Agric. Water Manag. 80: 212-224.

https://doi.org/10.1016/j.agwat.2005.07.014

Cramer, G. R., Abdel-Basset, \& Seemann, J. R. (1990). Salinity calcium interactions on root growth and osmotic adjustment of two corn cultivars differing in salt tolerance. J. Plant Nutr., 13: 1453-1462. https://doi.org/10.1080/01904169009364165

Datta, J. K., Nag, S., Banerjee, A., \& Mondal, N. K. (2009). Impact of salt stress on five varieties of wheat (Triticumaestivum L.) cultivars under laboratory condition. Journal of Applied Science and Environment Management, 13(3): 93-97.

Farooq, M., Hussain, M., Wakeel, A., \& Siddique, K. H. M. (2015). Salt stress in maize: effects, resistance mechanisms, and management. A review.Agronomy for Sustainable Development, Springer Verlag/EDP Sciences/INRA, 35(2), 461-481.

https://doi.org/10.1007/s13593-015-0287-0

Fita, A., Rodríguez-Burruezo, A., Boscaiu, M., Prohens, J., \& Vicente, O. (2015). Breeding and domesticating crops adapted to drought and salinity: a new paradigm for increasing food production. Front. Plant Sci., 12(6): 978. https://doi.org/10.3389/fpls.2015.00978

Giaveno, C. D., Ribeiro, R. V., Souza, G. M., \& de Oliveira, R. F. (2007). Screening of tropical maize for salt stress tolerance. Crop Breed. Appl. Biotech., 7: 304-313.

https://doi.org/10.12702/1984-7033.v07n03a10

Gupta, B., \& Huang, B. (2014). Mechanism of salinity tolerance in plants: physiological, 
biochemical, and molecular characterization. Int J Genom. doi:10.1155/2014/701596 https://doi.org/10.1155/2014/701596

Hameed, M., Naz, N., Ahmad, M. S. A., \& Islam-Ud-Din, Riaz, A. (2008). Morphological adaptations of some grasses from the salt range, Pakistan. Pak. J. Bot., 40(4): 1571-1578.

Hoque, M. M. I., Jun, Z., \& Guoying, W. (2015). Evaluation of salinity tolerance in maize (Zea mays L.) genotypes at seedling stage.J. BioSci. Biotechnol, 4(1): 39-49.

Hussain, K., Majeed, A., Nawaz, K., Bhatti, K. H., \& Nisar, F. K. (2009). Effect of different levels of salinity on growth and ion contents of black seeds (Nigella sativa L.). Curr. Res. J. Biol. Sci., 1(3): 135-138.

Khan, A. A., Rao, S. A., \& McNeilly, T. (2003). Assessment of salinity tolerance based upon seedling root growth response functions in maize (Zea mays L.). Euphytica, 13: 81-89.

https://doi.org/10.1023/A:1023054706489

Kochak-Zadeh, A., Mousavi, S., \& Nejad, M. (2013).The effect of salinity stress on germination and seedling growth of native and breeded varieties of wheat. J. Nov. Appl. Sci. 2(12): 703- 709 .

Lianes, A., Reinoso, H., \& Luna, V. (2005). Germination and early growth of Prosopisstrombuliferaseedlings in different saline solutions. World J. Agric. Sci., 1(2): 120-128.

Maiti, R. K., Amaya, L. E. D., Cardona, S. I., Dimas, A. M. O., Dela Rosa-Ibarra, M., \& Castillo, H. D. L. (1996). Genotypic variability in maize (Zea mays L.) cultivars for salinity resistance to drought and salinity. J. Plant Physiol., 148: 741-744.

https://doi.org/10.1016/S0176-1617(96)80377-4

Maiti, R., Rodríguez, H. G., Rajkumar, D., Koushik, S., \& Vidyasagar, P. (2012). Genotypic Variability in Salinity Tolerance of Maize Pipe Line Hybrids at Seedling Stage International Journal of Bio-resource and Stress Management 2012, 3(4):427-432

Mohammad, M., Shibli, R., Ajouni, M., \& Nimri, L. (1998). Tomato root and shoot responses to salt stress under different levels of phosphorus nutrition. J. Plant. Nutr., 21: 1667-1680.

https://doi.org/10.1080/01904169809365512

Munns, R., James, R. A., \& Läuchli, A. (2006). Approaches to increasing the salt tolerance of wheat and other cereals. J. Exp. Bot., 57: 1025-1043.

https://doi.org/10.1093/jxb/erj100

Munns, R., \& Tester, M. (2008). Mechanisms of salinity tolerance. Annu. Rev. Plant Biol., 59: 651-681. https://doi.org/10.1146/annurev.arplant.59.032607.092911

Munns, R. (2002). Comparative physiology of salt and water stress. Plant Cell Environ., 25: 239-250. https://doi.org/10.1046/j.0016-8025.2001.00808.x

Nordquist, P. T., Hergert, G. W., Skates, B. A., Compton, W. A., \& Marwell, J. P. (1992). Phenotypic expression of different maize hybrid genotypes grown in saline-sodic soil. 


\section{MInstitute Macrothink $_{\text {Int }}$}

Journal of Plant Nutrition, 15: 2137-2144.

https://doi.org/10.1080/01904169209364463

Ouda, S. A. E., Mohamed, S. G., \& Khalil, F. A. (2008). Modeling: The effect of different stress conditions on maize productivity using yield-stress model. Int. J. Natural Eng. Sci., 2(1): 57-62.

Pessarakli, M., \& Kopec, D. M. (2009). Screening various ryegrass cultivars for salt stress tolerance. J. Food Agric. Environ., 7(3,4): 739-743.

Pitman, M. G., \& Läuchli, A. (2002). Global impact of salinity and agricultural ecosystems. In: Salinity: Environment - Plants - Molecules, A. Läuchli and U. Lüttge (Eds.). Kluwer Academic Publishers, Dordrecht, 3-20.

Shalhevet, J. (1995). Using marginal quality water for crop production. Int. Water Irrig. Rev., 15(1): 5-10.

Shrivastava, P., \& Kumar, R. (2015). Soil salinity: a serious environmental issue and plant growth promoting bacteria as one of the tools for its alleviation. Saudi Journal of Biological Sciences, 22(2): 123-131. https://doi.org/10.1016/j.sjbs.2014.12.001

Slam, I., Abdell, C., Bouchereau, A., Flowers, T., \& Savoure, A. (2015). Diversity, distribution and roles of osmoprotective compounds accumulated in halophytes under abiotic stress. Annals of Botany, 115, 433-447. https://doi.org/10.1093/aob/mcu239

Tester, M., \& Davenport, R. (2003). NaR tolerance and NaR transport in higher plants. Ann Bot (Lond) 91: 503-527. https://doi.org/10.1093/aob/mcg058

USDA (United States Department of Agriculture). (2017). World Agricultural Supply and Demand Estimates. Accessed on Oct, 15, 2017.

Wicke, B., Smeets, E., Dornburg, V., Vashev, B., Gaiser, T., Turkenburg, W., \& Faaij, A. (2011). The global technical and economic potential of bioenergy from salt-affected soils. Energy \& Environmental Science, 4: 2669-2681. https://doi.org/10.1039/c1ee01029h

Yamaguchi, T., \& Blumwald, E. (2005). Developing salt-tolerant crop plants: challenges and opportunities. Trends in Plant Science, 10: 615-620.

https://doi.org/10.1016/j.tplants.2005.10.002

\section{Copyright Disclaimer}

Copyright for this article is retained by the author(s), with first publication rights granted to the journal.

This is an open-access article distributed under the terms and conditions of the Creative Commons Attribution license (http://creativecommons.org/licenses/by/4.0/). 